\title{
Two myrmecophilous scale insects, Cryptostigma urichi (Cockerell) (Hemiptera, Coccidae) and Farinococcus multispinosus Morrison (Hemiptera, Pseudococcidae), cohabiting inside branches of Anadenanthera falcata (Benth.) Speg. (Fabales, Fabaceae) in the Cerrado area of São Paulo State, Brazil
}

\author{
André R. Nascimento ${ }^{1}$, Ana L. B. G. Peronti² \& Takumasa Kondo ${ }^{3}$
}

\begin{abstract}
'Programa de Pós Graduação em Ecologia e Recursos Naturais, Departamento de Ecologia e Biologia Evolutiva, Universidade Federal de São Carlos, Via Washington Luiz Km 235, Caixa Postal 676, 13565-905 São Carlos-SP, Brasil. andre110479@yahoo.com.br

${ }^{2}$ Departamento de Ecologia e Biologia Evolutiva, Universidade Federal de São Carlos, Via Washington Luiz Km 235, Caixa Postal 676, 13565-905 São Carlos-SP, Brasil. anaperonti@hotmail.com

${ }^{3}$ Centro de Investigación Palmira, Corpoica (Corporación Colombiana de Investigación Agropecuaria), Calle 23, Carrera 37, Continúo al Penal, Palmira, Valle, Colombia. tkondo@corpoica.org.co
\end{abstract}

\begin{abstract}
Two myrmecophilous scale insects, Cryptostigma urichi (Cockerell) (Hemiptera, Coccidae) and Farinococcus multispinosus Morrison (Hemiptera, Pseudococcidae), cohabiting inside branches of Anadenanthera falcata (Benth.) Speg. (Fabales, Fabaceae) in the Cerrado area of São Paulo State, Brazil. The soft scale Cryptostigma urichi (Cockerell, 1894) and the mealybug Farinococcus multispinosus Morrison, 1922 are reported cohabiting inside branches of Anadenanthera falcata (Benth.) Speg. (Angico-preto), both tended by the ant Azteca oecocordia Longino, 2007 (Hymenoptera, Formicidae). This interaction was observed in the Cerrado region sensu stricto, at the Federal University of São Carlos, UFSCar, Brazil. A. oecocordia is recorded for the first time in Brazil.
\end{abstract}

KEYWORDS. Ant-coccoids interaction; Azteca oecocordia; trophobiotic interactions.

RESUMO. Duas cochonilhas mirmecófilas, Cryptostigma urichi (Cockerell) (Hemiptera, Coccidae) e Farinococcus multispinosus Morrison (Hemiptera, Pseudococcidae), coabitando no interior de ramos de Anadenanthera falcata (Benth.) Speg. (Fabales, Fabaceae) em área de Cerrado do Estado de São Paulo, Brasil. O coccídeo Cryptostigma urichi (Cockerell, 1894) e o pseudococcídeo Farinococcus multispinosus Morrison, 1922 são registrados coabitando no interior de galhos de Anadenanthera falcata (Benth.) Speg. (Angico-preto), ambos atendidos pela formiga Azteca oecocordia Longino, 2007 (Hymenoptera, Formicidae). Essa interação foi observada em uma região de Cerrado sensu stricto, na Universidade Federal de São Carlos, UFSCar, Brasil. A. oecocordia é registrada pela primeira vez para o Brasil.

PALAVRAS-CHAVE. interação formiga-cocóideos; Azteca oecocordia; interações trofobióticas.

Ants establish mutualistic relationships with a large number of species of Coccoidea and other Sternorrhyncha. The coccoids constantly produce honeydew upon which the ants feed, and in return, this association can improve the survival of coccoids because the ants provide protection against the action of natural enemies and their constant collecting of honeydew reduces contamination of the coccoids by molds that often grow on the excreted honeydew (Way 1963; Gullan 1997; Flatt \& Weisser 2000; Kondo \& Gullan 2004). This kind of relationships between an ant and a homopteran in which trade-off of a sweet food source occurs benefiting both organisms and improving their lives can be called trophobiosis (Holldobler \& Wilson 1990; Delabie 2001).

Trophobiotic interactions between coccoids and ants of the genus Azteca Forel, 1878 are estimated to have started in the Miocene period 15-20 million years ago (Johnson et al. 2001) and have been observed inside domatias of trees for a long time (Beccari 1884 apud Wheeler 1942; Longino 2007).

Cryptostigma Ferris, 1922 (Coccoidea, Coccidae), a Neotropical genus recently revised by Kondo (2010), is comprised of 17 species which live mostly inside the hollow branches, twigs or trunks of their host plants in association with ants belonging to four different subfamilies: Dolichoderinae, Formicinae, Myrmicinae and Pseudomyrmecinae (Ferris 1922; Laing 1925; Morrison 1922, 1929; Newstead 1917, 1920; Qin \& Gullan 1989; Kondo 2010), and rarely with stingless bees (Apidae, Meliponini) (Camargo and Pedro 2002a, b; Kondo 2010).

Cryptostigma urichi (Cockerell), one of the four species of Cryptostigma known from Brazil, has been reported from Belize, Brazil (Rio Grande do Sul), Colombia, Grenada, 
Guyana, Suriname, Trinidad and Tobago associated with Azteca alfari cecropiae Forel, Azteca sp., Camponotus novogrenadensis Mayr (within nests of the termite Hamitermes excellens Emerson) and Crematogaster brevispinosa Mayr (Hempel 1900; Morrison 1922, 1929 apud Kondo 2010). Host plants of C. urichi include various species of Cecropiaceae, Fabaceae, Malvaceae (as Sterculiaceae), Moraceae, Polygonaceae, and Smilacaceae (Kondo 2010).

Farinococcus multispinosus Morrison is a unique species within Farinococcus, and it is known from Brazil, Costa Rica and Guyana. This species has been reported cohabiting with two species of Cryptostigma in Guyana: with C. urichi inside domatia of Triplaris surinamensis tended by the ant Pseudomyrma triplaridis (Wheeler 1942); and with $C$. inquilinum (Newstead), in internodes of branches of Triplaris weigeltiana, tended by Pseudomyrmex viduus (Ward 1999).

Cryptostigma urichi, Farinococcus multispinosus and Azteca oecocordia Longino, 2007 (Fig. 1) were first observed inside branches of Anadenanthera falcata (Fabaceae), in December 2008, in the Cerrado sensu stricto at the Universidade
Federal de São Carlos, (UFSCar), located between the coordinates $21^{\circ} 58^{\prime} 22^{\circ} 00^{\prime \prime S}$ and $47^{\circ} 51^{\prime} 47^{\circ} 52^{\prime \prime} \mathrm{W}$. Additional collections were made in the same place: January and August 2009, December 2011, and January 2012 in order to confirm these novel scale insect-ant mutualistic interactions.

In the first collections, plants of A. falcata, were chosen at random, and the branches were opened with a knife, and the coccoids and ants, when present, were stored separately in $75 \%$ and $95 \%$ ethanol respectively to posterior slide-mounting and identification. In the last collection, 20 trees of variable sizes were chosen. For each tree, one segment of $30 \mathrm{~cm}$ from different branches were sampled and all scale insects and ants found inside were quantified and calculated the simple mean $(\bar{x})$ and standard deviation $(s d)$. The basal diameter of the tree trunks of these trees were measured (Brito 1997).

Permanent slides of the specimens were prepared following the method for Coccoidea used by Gullan (1984). The species were identified under an optical microscope, using the keys by Williams \& Granara de Willink (1992) for mealybugs, Hodgson (1994) for Coccidae genera, and Kondo
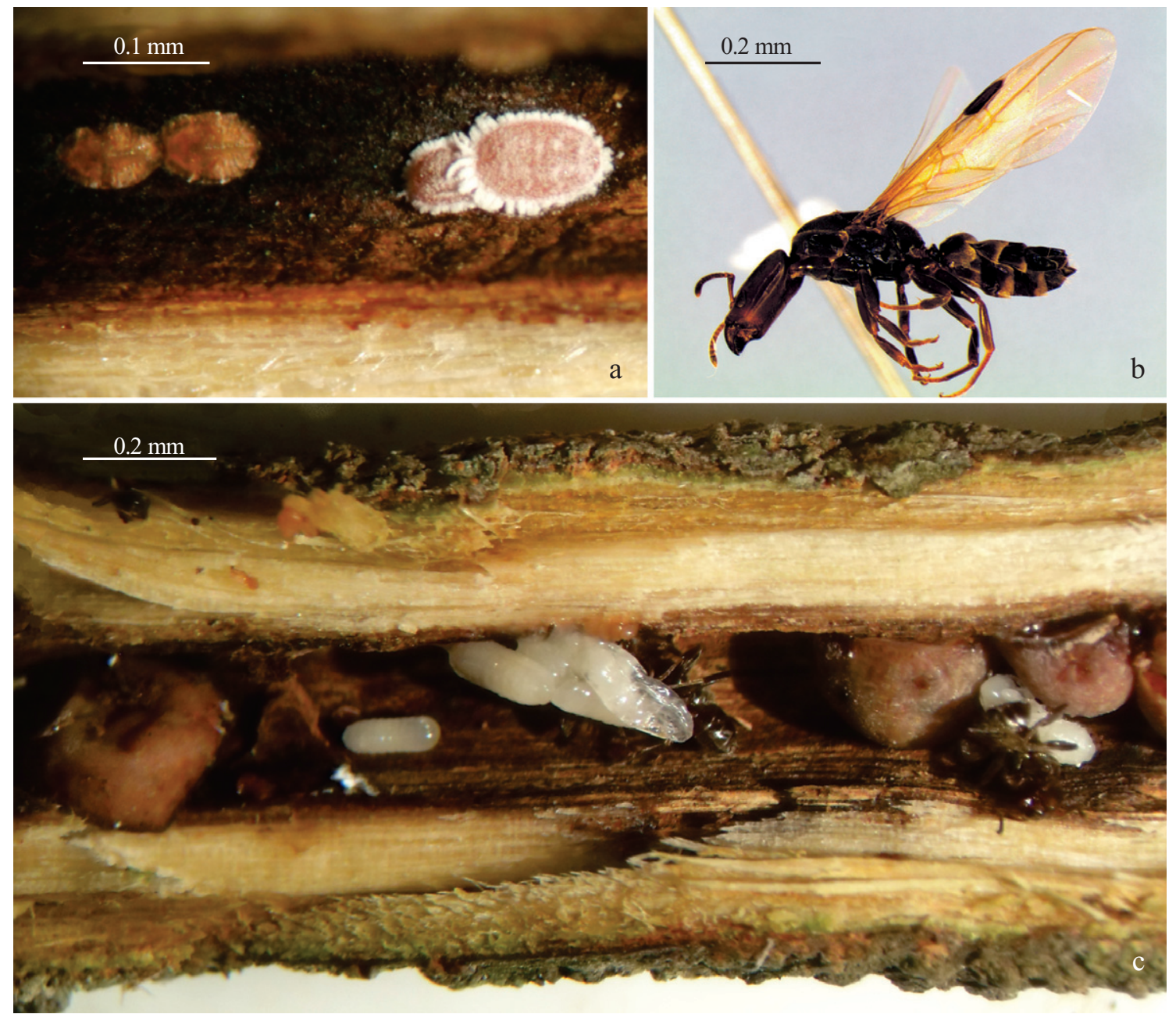

Fig. 1. Scale insects cohabiting in branches of Anadenathera falcata within Azteca oecocordia colony. a) Cryptostigma urichi (left) and Farinococcus multispinosus (right) cohabiting inside branches of Anadenanthera falcata; b) Queen of A. oecocordia; c) Nest of the Azteca oecocordia associated with Cryptostigma urichi. 
(2010) for coccids of the genus Cryptostigma. The ants were sent to a specialist for identification. The insects were deposited in the entomological collection of the Department of Ecology and Evolutionary Biology at UFSCar.

The coccoids $C$. urichi and F. multispinosus and the ant A. oeococordia were observed within the hollow branches in at least one tree of A. falcata, in all periods sampled. Groups of these two species of coccoids were observed alone or cohabiting the same hole, together with the ants (Fig. 1a).

The scale insects were found in nine $(45 \%)$ of the trees sampled. Of the two species of scale insects observed, $C$. urich $i$ was the most abundant with $0-20(\overline{\mathrm{x}}=2.35 ; s d=4.68)$ specimens in each hollow branch sampled. Specimens of $F$. multispinosus when present, only 1-5 specimens were observed in each hollow branch. All life stages of both coccoids were present, indicating that these two coccoid species complete their life cycles inside the branches of $A$. falcata. The number of $A$. oecocordia ants (Fig. 1b) found inside the opened branches was $0-178(\overline{\mathrm{x}}=12.25$; $s d=42.71)$ specimens in $8(40 \%)$ sampled trees. Nests with immature ants were found inside the branches, always near the $\mathrm{C}$. uruchi aggregations (Fig. 1c).

Both, ants and scale insects were found inhabiting branches from $1 \mathrm{~cm}$ in diameter in young and older trees. Cryptostigma urichi was most common in trees with tree trunks with more than $0.36 \mathrm{~cm}$ of basal diameter and $F$. multispinosus was also present in younger trees with tree trunks from $0.12 \mathrm{~cm}$ of basal diameter.

No natural enemies were observed to be associated with the coccoids. The ants were very aggressive when the coccoids were manipulated, indicating that they provide protection to the coccoids. Furthermore, these insects gain additional protection from natural enemies due to their habit of living inside hollow branches that provide isolation from the external environment.

The hollow branches in which the scale insects were found had small entrance holes from which the ants entered and exited. Anadenanthera falcata apparently does not have natural domatia, and thus the hollow branches were probably tunneled by the ants or other xylophagous herbivores that may have previously inhabited these spaces.

According to the literature, the introduction of scale insects inside holes of domatia or other kind of cavities present in the host plants, could occur in two ways: scale insects (immatures or adult females) could be transported by ants (workers or founding queens); or the crawlers could walk by themselves to enter the holes (Gullan 1997; Delabie 2001; Johnson et al. 2001; Moog et al. 2005). Although Kutscher \& Koteja (2000) described and illustrated the fossil of a female of Matsucoccus species (Hemiptera, Coccoidea, Matsucoccidae) held between mandibles of an ant, Azteca sp. that were both preserved in Dominican amber, no extant Azteca ant species have been recorded transporting coccid and pseudococcid species. Nevertheless, it still remains uncertain the way in which these scale insects were introduced into the hollow branches of $A$. falcata in this study.
Azteca oecocordia described by Longino (2007) is known only from Monteverde in Costa Rica, living in a specific association with Cordia alliodora (Longino 2007). Despite the morphological similarity between Brazilian and Costa Rican specimens of $A$. oecocordia, phylogenetic analysis should be conducted in order to evaluate some possible interspecific convergences (J. Longino pers. com.). Azteca oecocordia is reported for the first time in Brazil.

\section{ACKNOWLEDGMENTS}

Thanks to Dr. Rodrigo Machado Feitosa of the Museu de Zoologia da Universidade de São Paulo (MZUSP) and Dr. John T. Longino (The Evergreen State College, Olympia, Washington) for the identification and confirmation of the ant species Azteca oecocordia, respectively. Dr. Penelope J. Gullan (Division of Evolution, Ecology \& Genetics, Research School of Biology, The Australian National University, Canberra, Australia) for reviewing this paper. The Instituto Nacional de Ciência e Tecnologia de Hymenoptera Parasitóides da Região Sudeste Brasileira (HYMPAR/SUDESTE) and the Coordenação de Aperfeiçoamento de Pessoal de Nível Superior (CAPES) are acknowledged for supporting this study.

\section{REFERENCES}

Beccari, O. 1884. Piante ospitatrici ossia formicarie della Malesia e della Papuasia. Malesia 2: 1-340.

Brito, M. C. W. (coord.). 1997. Cerrado: Bases para conservação e uso sustentável das áreas de cerrado do Estado de São Paulo. São Paulo, Série PROBIO/SP, Secretaria do Meio Ambiente, 184 p.

Camargo, J. M. F. \& S. R. M. Pedro. 2002a. Mutualistic association between a tiny Amazonian stingless bee and a wax-producing scale insect. Biotropica 34: 446-451.

Camargo, J. M. F. \& S. R. M. Pedro. 2002b. Uma espécie nova de Schwarzula da Amazonia (Hymenoptera, Apidae, Meliponini). Iheringia, série Zoologia, 92: 101-112.

Delabie, J. H. C. 2001. Trophobiosis between Formicidae and Hemiptera (Sternorrhyncha and Auchenorrhyncha): an overview. Neotropical Entomology 30: 501-516.

Ferris, G. F. 1922. Notes on Coccidae - IX. (Hemiptera). Canadian Entomologist 54:156-161.

Flatt, T. \& W. W. Weisser. 2000. The effects of mutualistic ants on aphid life history traits. Ecology 81: 3522-3529.

Gullan, P. J. 1984. A revision of the gall-forming coccoid genus Apiomorpha Rübsaaman (Homoptera: Eriococcidae: Apiomorphinae). Australian Journal of Zoology, Supplementary Series, 97: 1-203.

Gullan, P.J. 1997. Relationships with ants, p.351-373. In Y. Ben-Dov \& C.J. Hodgson (eds.), Soft scale insects: Their biology, natural enemies and control, volume 7A. Elsevier Science, Amsterdam, 452 p.

Hempel, A. 1900. As coccidas brasileiras. Revista do Museu Paulista 4 : 365-537.

Hodgson, C. J. 1994. The Scale Insect Family Coccidae. An Identification Manual to Genera. Wallingford, CAB International, vi+639 p.

Hölldobler, B. \& Wilson, E. O. 1990. The ants. Cambridge, Harvard University Press, $732 \mathrm{p}$.

Johnson C.; D. Agosti; J. H. Delabie; K. Dumpert; D. J. Williams; M. von Tschirnhaus \& U. Maschwitz. 2001. Acropyga and Azteca ants (Hymenoptera: Formicidae) with scale insects (Sternorrhyncha: Coccoidea): 20 million years of intimate symbiosis. American Museum Novitates 3335: 1-18.

Revista Brasileira de Entomologia 56(4): 511-514, dezembro, 2012 
Kondo, T. 2010. Taxonomic revision of the myrmecophilous, meliponiphilous and rhizophilous soft scale genus Cryptostigma Ferris (Hemiptera: Coccoidea: Coccidae). Zootaxa 2709: 1-72.

Kondo, T. \& P. J. Gullan. 2004. A new species of ant-tended soft scale of the genus Cryptostigma Ferris (Hemiptera: Coccidae) associated with bamboo in Peru. Neotropical Entomology 33: 717-723.

Kutscher M. \& J. Koteja. 2000. Coccids and aphids (Hemiptera: Coccinea, Aphidinea), prey of ants (Hymenoptera: Formicidae): evidence from Bitterfeld amber. Polskie Pismo Entomologiczne 69: 179_ 185.

Laing, F. 1925 Descriptions of some new genera and species of Coccidae. Bulletin of Entomological Research 16: 51- 66.

Longino, J. T. 2007. A taxonomic review of the genus Azteca (Hymenoptera: Formicidae) in Costa Rica and a global revision of the aurita group. Zootaxa 1491: 1-63.

Morrison, H. 1922. On some trophobiotic Coccidae from British Guiana. Psyche 29: 132-152.

Morrison, H. 1929. Some neotropical scale insects associated with ants (Hemiptera - Coccidae). Annals of the Entomological Society of America 22: 33-60.
Moog, J.; L. G. Saw; R. Hashim \& U. Maschwitz. 2005. The triple alliance: how a plant-ant, living in an ant-plant, acquires the third partner, a scale insect. Insectes Sociaux 52: 169-176.

Newstead, R. 1917. Observations on scale-insects (Coccidae) - III. Bulletin of Entomological Research 7: 343-380.

Newstead, R. 1920. Observations on scale-insects (Coccidae) - VI. Bulletin of Entomological Research 10: 175-207.

Qin, T. K. \& P. J. Gullan. 1989. Cryptostigma Ferris: A coccoid genus with a strikingly disjunct distribution (Homoptera: Coccidae). Systematic Entomology 14: 221-232.

Ward, P. S. 1999. Systematics, biogeography and host plant as associations of the Pseudomyrmex viduus group (Hymenoptera: Formicidae), Triplaris- and Tachigali-inhabiting ants. Zoological Journal of the Linnean Society 126: $451-540$.

Way, M. J. 1963. Mutualism between ants and honeydew-producing Homoptera. Annual Review Entomology 8: 307-344.

Wheeler, W. M. 1942. Studies of neotropical ant-plants and their ants. Bulletin of the Museum of Comparative Zoology 90: 1-262.

Williams, D. J. \& M. C. Granara de Willink. 1992. Mealybugs of Central and South America. London, CAB International, 635 p.

Received 10/8/2011; accepted 15/11/2012

Editor: Márcio Roberto Pie 